\title{
Synthesis and Spectroscopic Studies of new ligand N-((4- (phenylamino)phenyl)carbamothioyl)acetamide with some Divalent Metal Ion Complexes
}

\author{
Basima M.Sarhan, Ban Z. Neema \\ Dep. Of chemistry, Collage of Education for pure sciences $\backslash$ Ibn-AL-Hatham, University of \\ Baghdad . \\ G-mail/ Bana.che81@gmail.com
}

\begin{abstract}
A new ligand $\mathrm{N}-((4-$ (phenylamino) phenyl) carbamothioyl) acetamide (PCA) was synthesized by reaction of (4-amino di phenyl amine) with (acetyl isothiocyante) by using acetone as a solvent. The prepared ligand(PCA) has been characterization by elemental analysis (CHNS), infrared(FTIR),electronic spectral (UV-Vis) $\&{ }^{1} \mathrm{H},{ }^{13} \mathrm{C}$ - NMR spectra. Some Divalent Metal ion complexes of ligand (PCA) were prepared and spectroscopic studies by infrared(FT-IR), electronic spectral (UVVis), molar conductance, magnetic susceptibility and atomic absorption. The results measured showed the formula of all prepared complexes were $\left[\mathrm{M}(\mathrm{PCA})_{2} \mathrm{Cl}_{2}\right] \quad\left(\mathrm{M}^{+2}=\mathrm{Mn}, \mathrm{Co}, \mathrm{Ni}, \mathrm{CU}, \mathrm{Zn}, \mathrm{Cd}\right.$ $\& \mathrm{Hg}$ ), the proposed geometrical structure for all complexes were octahedral.
\end{abstract}

Key Word: 4-Amino di phenyl amine, Divalent Metal Ion, Complexes

\section{Introduction}

Aromatic amines are a class of chemicals found in the plastic and chemical industries as products of the manufacturing of compounds such as polyurethane foams, dyes, pesticides, pharmaceuticals and semiconductors They are also found in environmental pollutions such as diesel exhaust, combustion of wood chips \& rubber, tobacco smoke \& substancesin grilled meats and fish [1-2]. There are three types of aromatic amines: monocylic, polycyclic \& heterocyclic.

Aromatic amines and heterocyclic aromatic amines are structurally related classes of carcinogens that are formed during the combustion of tobacco or during the hightemperature cooking of meats[3]. (4- amino diphenylaamine) a heterocyclic aromatic amine was used widely to synthesis a new ligands such as Md. Serajul H. Faizi and coworker[4] synthesized new Schiff bases N
1-[(1H-Imidazol -2-yl )methylidene]-N 4phenyl -benzene -1,4-diamine,also in 2015 Eslam Salahifara\& Davood Nematollahi [5]were study electrochemical generation of a Michael acceptorr: a green method for the synthesis of 4-amino -3-(phenylsulfonyl) diphenylamine derivatives, also Ammar Jihad Alabdali[6]was prepared new ligand (N-PAmino Diphenyl Amine) Amino( 2Hydroxyi Phenyl) Acetonitrile with Fe (II), $\mathrm{Co}$ (II), $\mathrm{Ni}$ (II) and $\mathrm{Cu}$ (II) Metal Ions.

The aim of this work is prepare new ligand [N-((4-(phenylamino) phenyl) carbamothioyl) acetamide] (PCA), and it's metal complexes with Mnganes ion, Cobalte ion, Nickle ion, Cupper, Znic ion\& Cadimum ion \& Merrcari ion.

\section{Experimental \\ Chemicals}

The chemicals(4- amino diphenyl amine, acetyl chloride, metals chloride salts and all solvents) used in this work were all of reagent grade by BDH, Merck and Fluka. 


\section{Instruments}

- ${ }^{1} \mathrm{H}$ and ${ }^{13} \mathrm{C}-\mathrm{NMR}$ were recorded using Ultra Shield $300 \quad \mathrm{MH}_{\mathrm{z}}$ Switzerland at Unv. Of Al al -Bayt, Jordan.

- Melting point was recorded by using melting point meter KRUSS (A, KRUSS OPTRONIC).

- "FT-IR spectra "were recorded as FT-IR using 3800 Shimadzu in the range of (4000$400) \mathrm{cm}^{-1}$ by using $(\mathrm{KBr})$ disc for ligand and in the range(4000-200) $\mathrm{cm}^{-1}$ by using (CsI) disc for complexes.

- Electronic spectra "were obtained using UV-160 Shimadzu spectrophotometer at $25^{\circ} \mathrm{C}$ for $10^{-3} \mathrm{M}$ solution DMSO with $1.000 \pm$ $0.001 \mathrm{~cm}$ at ched quartz cel.

- Molar Conductivity was measured at $25^{\circ} \mathrm{C}$ for $10^{-3} \mathrm{M}$ solution of DMSO by using Philips PW.

- Digital micro elemental analysis(C.H.N.S) were using Acrlo Erba 1106elemental analyzer.

- Magnetic susceptibility measurements were obtained by balance magnetic susceptibility model MSB -MKI.

- Metal contents of the complexes were determined by atomic absorption technique by using Shimadzu(AA680G ).

\section{Preparation of ligand(PCA)}

Its contain two step :

\section{(1) Synthesis of compound (acetyl isothiocyanate) :}

Mixture of $(2 \mathrm{~g}, 26 \mathrm{mmol})$ of (ammonium thiocyanate)with $(1.84 \mathrm{~mL}, 26 \mathrm{mmol})$ of (acetyl chloride) in $(25 \mathrm{ml})$ of acetone was stirred for (3 hrs.) and then filtered.

(2)Synthesis of Ligand N((4(phenylamino)phenyl)carbamothioyl) acetamide(PCA) :

$(4.79 \mathrm{~g}, 26 \mathrm{mmol})$ of 4-amino diphenyl amine in $(20 \mathrm{ml})$ acetone was rapidly added to the solution was prepare in step(1) and reflux. After refluxing for( $6 \mathrm{hrs}$.), the resulting solid was collected, washed with acetone and recrystallization from ethanol, as in scheme(1). Yield(88\%), (m.p $=112-114)^{\circ} \mathrm{C}, \mathrm{C} \%$ found (63.14) calc.( 63.13), $\mathrm{H} \%$ found (5.22), calc.( 5.30),N\% found (14.09), calc.( 14.73),S\% found (11.59), calc.(11.24).

\section{Synthesis of ligand (PCA) complexes:}

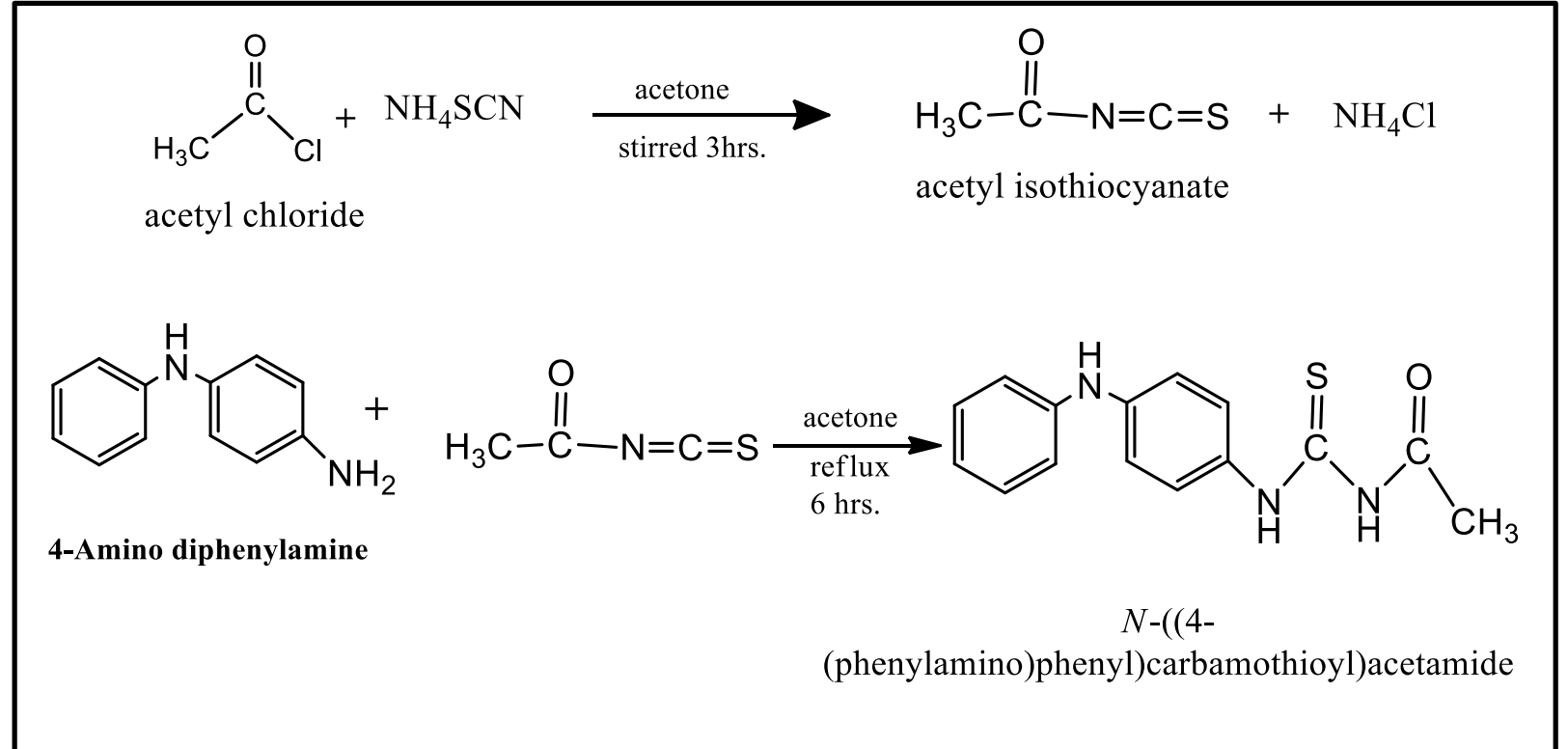


The complexes $\left[\mathrm{M}(\mathrm{PCA})_{2} \mathrm{Cl}_{2}\right.$ ] have been prepared by the reaction of $(0.57 \mathrm{~g}, 2 \mathrm{mmol})$ of ligand(PCA) in $(10 \mathrm{ml})$ ethanol with $(1 \mathrm{mmol})$ of metal chloride $(0.20 \mathrm{gm}$, $0.237 \mathrm{gm}, 0.17 \mathrm{gm}, 0.237 \mathrm{gm}, 0.14 \mathrm{gm}, 0.20 \mathrm{gm}$ and $0.271 \mathrm{gm}$ for $\mathrm{MnCl}_{2} \cdot 4 \mathrm{H}_{2} \mathrm{O}, \quad \mathrm{CoCl}_{2} \cdot 6 \mathrm{H}_{2} \mathrm{O}$, $\mathrm{CuCl}_{2} \cdot 2 \mathrm{H}_{2} \mathrm{O}, \mathrm{NiCl}_{2} \cdot 6 \mathrm{H}_{2} \mathrm{O}, \mathrm{ZnCl}_{2}, \mathrm{CdCl}_{2} \cdot \mathrm{H}_{2} \mathrm{O}$ and $\mathrm{HgCl}_{2}$ )respectively dissolved in $(20 \mathrm{ml})$ absolute ethanol \& refluxed with stirring under anhydrous conditions for 3 hours at room temperature, the precipitate was collected by filtration, washed with(1:1) mixture of water: ethanol and dried in an oven $\left(50^{\circ} \mathrm{C}\right)$. Table $(1)$ exhibit some physical properties of the prepared complexes.

\section{Results and Discussion}

\section{Ligand (PCA)}

-The" ${ }^{11} \mathrm{H}-\mathrm{NMR}$ "spectrum of the ligand (PCA) Fig(1) in DMSO showed the following signals: signal peak at $\delta(2.26) \mathrm{ppm}$ for $(1 \mathrm{H}, \mathrm{NH}$ Sec amine), singlet peak at $\delta(2.5) \mathrm{ppm}$ for DMSO, single peak at $\delta(3.48)$ ppm for $(3 \mathrm{H}, \mathrm{CH} 3)$, multi peaks at $\delta(6.38-7.45) \mathrm{ppm}$ for (9H ,aromatic protons), singlet peak at $\delta(11.38)$ ppm for $(1 \mathrm{H}, \mathrm{NH}$ sec, amid), singlet peak at $\delta(12.35)$ ppm for(1H, NH Sec amine).

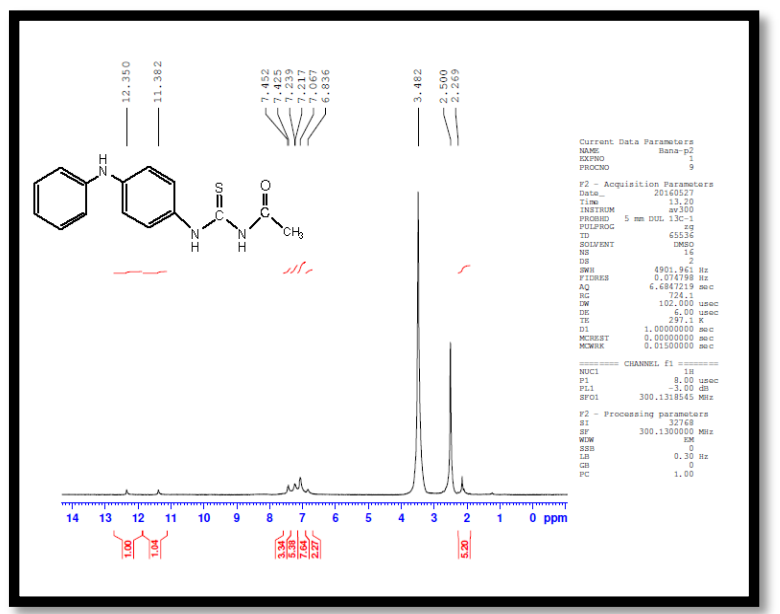

Fig(1): ${ }^{1} \mathrm{H}-\mathrm{NMR}$ spectrum of ligand (PCA)

-The ${ }^{13} \mathrm{C}-\mathrm{NMR}$ "spectrum of the ligand (PCA) in DMSO Fig.(2) showed the following signals: signal at $\delta(23.76) \mathrm{ppm}$ for $\left(\mathrm{CH}_{3}\right)$, signals at $\delta(38.63-42.84) \mathrm{ppm}$ for
DMSO, signals at $\delta(116.61-143.05) \mathrm{ppm}$ for aromatic carbons, signals at $\delta(172.66) \mathrm{ppm}$ for $(\mathrm{C}=$ Osec.amide), signal at $\delta$ (178.29) ppm for $(\mathrm{C}=\mathrm{S})[7-8]$.

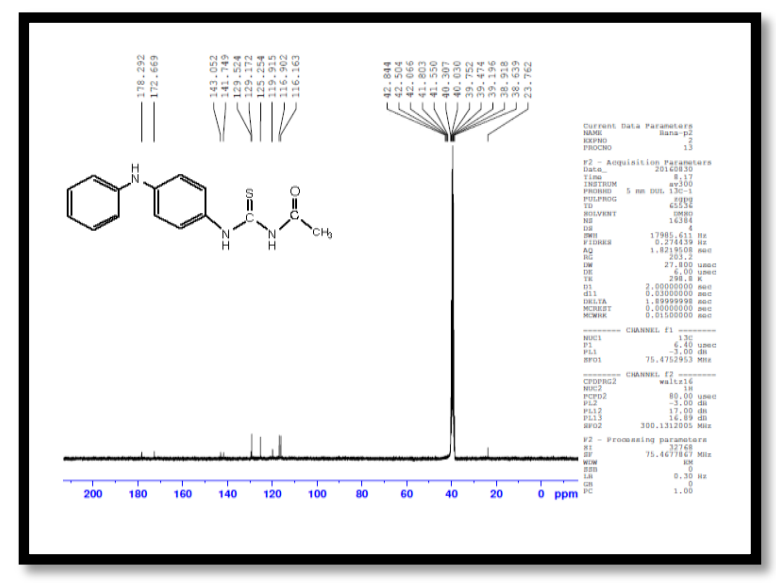

\section{Fig(2): ${ }^{13} \mathrm{C}-\mathrm{NMR}$ spectrum of ligand (PCA)}

-The "FT-IR" spectrum of the free ligand (PCA) Fig.(3)showed band at(3358) $\mathrm{cm}^{-1}$ due to $v(\mathrm{NH})$, strong band at $(1678) \mathrm{cm}^{-1}$ for $v(\mathrm{C}=\mathrm{O}$ amidic $)$ and anther band at $(1248) \mathrm{cm}^{-1}$ for $v(\mathrm{C}=\mathrm{S})$ [9-11].The FT-IR spectral data of the free ligand were listed in table(2).

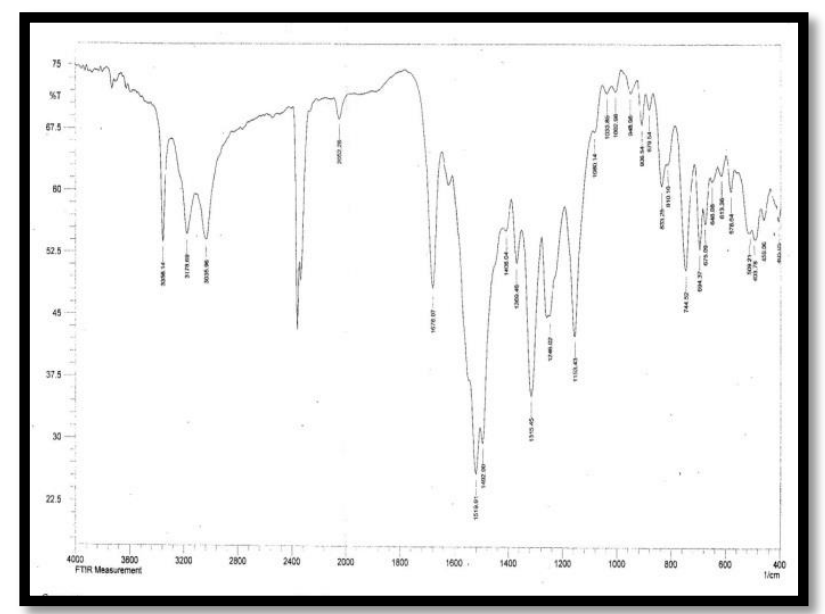

Figure (3): Infrared spectrum of ligand (PCA) 
AL-Qadisiyah Journal of pure Science $\quad$ Vol.23 No. 2 Year 2018

Table(1): Some physical properties of the complexes and its ligand

\begin{tabular}{|c|c|c|c|c|c|c|}
\hline Compound & $\begin{array}{c}\text { M.wt } \\
\text { (gm/mole) }\end{array}$ & Color & $\begin{array}{c}\text { M.P(C) } \\
\text { or } \\
\text { dec . }\end{array}$ & $\begin{array}{l}\text { M\% } \\
\text { Calculation } \\
\text { (Found) }\end{array}$ & $\begin{array}{c}\text { Molar Cond. } \\
\text { Ohm } \\
{ }_{1}^{-} \mathrm{cm}^{2} \mathrm{~mol}^{-1} \\
\text { in DMSO }\end{array}$ & $\begin{array}{c}\boldsymbol{\mu}_{\mathrm{eff}} \\
(\mathbf{B} \cdot \mathbf{M})\end{array}$ \\
\hline $\begin{array}{l}\text { Lignd(PCA) } \\
\mathrm{C}_{15} \mathrm{H}_{15} \mathrm{~N}_{3} \mathrm{OS}\end{array}$ & 285.36 & $\begin{array}{l}\text { Dark } \\
\text { green }\end{array}$ & $112-114$ & ------ & ------ & \\
\hline$\left[\mathrm{Mn}(\mathrm{PCA})_{2}(\mathrm{Cl})_{2}\right]$ & 698.59 & green & $150-152$ & $\begin{array}{c}7.14 \\
(7.30) \\
\end{array}$ & 6.72 & 5.94 \\
\hline$\left[\mathrm{Co}(\mathrm{PCA})_{2}(\mathrm{Cl})_{2}\right]$ & 702.58 & green & $120-122$ & $\begin{array}{c}8.39 \\
(8.44) \\
\end{array}$ & 13.09 & 4.49 \\
\hline$\left[\mathrm{Ni}(\mathrm{PCA})_{2}(\mathrm{Cl})_{2}\right]$ & 702.34 & green & $122-124$ & $\begin{array}{c}8.36 \\
(8.33) \\
\end{array}$ & 17.3 & 2.95 \\
\hline$\left[\mathrm{Cu}(\mathrm{PCA})_{2}(\mathrm{Cl})_{2}\right]$ & 707.20 & green & $142-144$ & $\begin{array}{c}8.99 \\
(9.00) \\
\end{array}$ & 14.01 & 1.76 \\
\hline$\left[\mathrm{Zn}(\mathrm{PCA})_{2}(\mathrm{Cl})_{2}\right]$ & 709.03 & green & $140-142$ & $\begin{array}{c}9.22 \\
(9.15) \\
\end{array}$ & 2.6 & 0 \\
\hline$\left[\mathrm{Cd}(\mathrm{PCA})_{2}(\mathrm{Cl})_{2}\right]$ & 756.06 & green & $\begin{array}{c}182-183 \\
\text { Dec. }\end{array}$ & $\begin{array}{c}14.87 \\
(13.67) \\
\end{array}$ & 7.48 & 0 \\
\hline$\left[\mathrm{Hg}(\mathrm{PCA})_{2}(\mathrm{Cl})_{2}\right]$ & 42.68 & green & $150-152$ & $\begin{array}{c}23.76 \\
(24.25)\end{array}$ & 12.8 & 0 \\
\hline
\end{tabular}

Dec. $=$ decompose

Table (2): The characteristics infrared band for free ligand (PCA) and its complexes

\begin{tabular}{|c|c|c|c|c|c|c|}
\hline Compound & $v(\mathbf{N}-\mathbf{H})$ & $\begin{array}{c}v(C=0) \\
\text { Amide }\end{array}$ & $v(\mathbf{C}=\mathbf{S})$ & $v(M-O)$ & $v(M-S)$ & $v(M-C l)$ \\
\hline $\begin{array}{c}\text { Ligand } \\
\text { (PCA) }\end{array}$ & $3356_{(\mathrm{m})}$ & $1678_{(\mathrm{s})}$ & $1246_{(\mathrm{s})}$ & - & - & - \\
\hline$\left[\mathrm{Mn}(\mathrm{PCA})_{2}(\mathrm{Cl})_{2}\right]$ & $3356_{(w)}$ & $1595_{(\mathrm{s})}$ & $1174_{(\mathrm{m})}$ & $422_{(\mathrm{m})}$ & $349_{(\mathrm{w})}$ & $281_{(\mathrm{m})}$ \\
\hline$\left[\mathrm{Co}(\mathrm{PCA})_{2}(\mathrm{Cl})_{2}\right]$ & $3355_{(\mathrm{w})}$ & $1596_{(\mathrm{w})}$ & $1170_{(\mathrm{s})}$ & $472_{(\mathrm{m})}$ & $372_{(\mathrm{m})}$ & $283_{(\mathrm{m})}$ \\
\hline$\left[\mathrm{Ni}(\mathrm{PCA})_{2}(\mathrm{Cl})_{2}\right]$ & $3357_{(w)}$ & $1596_{(\mathrm{m})}$ & $1174_{(\mathrm{m})}$ & $374_{(\mathrm{w})}$ & $343_{(\mathrm{m})}$ & $273_{(\mathrm{m})}$ \\
\hline$\left[\mathrm{Cu}(\mathrm{PCA})_{2}(\mathrm{Cl})_{2}\right]$ & $3353_{(w)}$ & $1593_{(w)}$ & $1176_{(\mathrm{m})}$ & $410_{(\mathrm{w})}$ & $345_{(\mathrm{m})}$ & $258_{(\mathrm{m})}$ \\
\hline$\left[\mathrm{Zn}(\mathrm{PCA})_{2}(\mathrm{Cl})_{2}\right]$ & $3348_{(w)}$ & $1596_{(w)}$ & $1174_{(\mathrm{m})}$ & $420_{(\mathrm{m})}$ & $341_{(w)}$ & $283_{(\mathrm{m})}$ \\
\hline$\left[\mathrm{Cd}(\mathrm{PCA})_{2}(\mathrm{Cl})_{2}\right]$ & $3353_{(w)}$ & $1596_{(w)}$ & $1174_{(\mathrm{m})}$ & $418_{(\mathrm{m})}$ & $364_{(w)}$ & $251_{(\mathrm{m})}$ \\
\hline$\left[\mathrm{Hg}(\mathrm{PCA})_{2}(\mathrm{Cl})_{2}\right]$ & $3350_{(w)}$ & $1596_{(\mathrm{m})}$ & $1174_{(\mathrm{m})}$ & $408_{(\mathrm{m})}$ & $378_{(\mathrm{m})}$ & $252_{(\mathrm{m})}$ \\
\hline
\end{tabular}

$$
\mathrm{s}=\text { strong } \quad \mathrm{m}=\text { medium } \quad \mathrm{w}=\text { week }
$$


-The "UV-Vis" spectrum of the free(PCA). Fig.(5)showed a high intense absorption peak at $(33222) \mathrm{cm}^{-1}$ which may impute to electronic transition type $\pi \rightarrow *^{*}[12]$.The data of electronic spectrum of the free ligand (PCA) were showed in table (3).

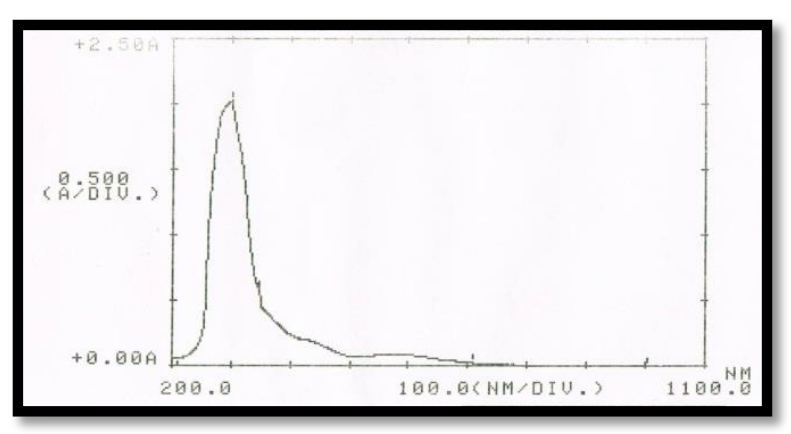

\section{Complexes of the ligand(PCA)}

All complexes soluble in some common solvent such as "dimethyl formamide", "dimethyl sulphoxide" and relatively thermally stable. The conductivity values for the complexes of $\left(10^{-3} \mathrm{M}\right)$ in DMSO were recorded in rang (3-17) $\mathrm{Ohm}^{-1} \mathrm{~cm}^{2} \mathrm{~mol}^{-1}$ indicating that the non-electrolytic nature of the complexes [13].The atomic absorption measurements for all complexes gave approximated values when its comparison with theoretical values, Table (1) includes the physical properties for the ligand and its complexes.

Fig(5): U.V spectrum of ligand (PCA)

Table (3)Electronic spectral data of ligand (APC) and its complexes

\begin{tabular}{|c|c|c|c|c|c|}
\hline compounds & $\lambda(\mathbf{n m})$ & $v\left(\mathrm{~cm}^{-1}\right)$ & $\mathbf{A B C}$ & $\underset{{\text { molar }-1 \mathrm{~cm}^{-1}}^{\boldsymbol{E}_{\max }}}{ }$ & Transitions \\
\hline $\begin{array}{l}\text { Ligand } \\
\text { PCA }\end{array}$ & 301 & 33222 & 2.025 & 2025 & $\pi \rightarrow \pi^{*}$ \\
\hline$\left[\mathrm{Mn}(\mathrm{PCA})_{2}(\mathrm{Cl})_{2}\right]$ & $\begin{array}{l}297 \\
420 \\
584\end{array}$ & $\begin{array}{l}33670 \\
23809 \\
17123\end{array}$ & $\begin{array}{l}2.272 \\
0.260 \\
0.129\end{array}$ & $\begin{array}{l}227 \\
260 \\
129\end{array}$ & $\begin{array}{l}\text { L.F. } \\
{ }^{6} \mathrm{~A}_{1} \mathrm{~g} \rightarrow{ }^{4} \mathrm{~T}_{2} \mathrm{~g}(\mathrm{G}) \\
{ }^{6} \mathrm{~A}_{1} \mathrm{~g} \rightarrow{ }^{4} \mathrm{~T}_{1} \mathrm{~g}(\mathrm{G})\end{array}$ \\
\hline$\left[\mathrm{Co}(\mathrm{PCA})_{2}(\mathrm{Cl})_{2}\right]$ & $\begin{array}{l}309 \\
435 \\
583 \\
933\end{array}$ & $\begin{array}{l}32362 \\
22988 \\
17152 \\
10718\end{array}$ & $\begin{array}{c}1.879 \\
0.154 \\
0.0100 \\
0.030\end{array}$ & $\begin{array}{c}1879 \\
154 \\
100 \\
30\end{array}$ & $\begin{array}{c}\text { L.F. } \\
{ }^{4} \mathrm{~T}_{1} \mathrm{~g} \rightarrow{ }^{4} \mathrm{~T}_{1} \mathrm{~g}(\mathrm{P}) \\
{ }^{4} \mathrm{~T}_{1} \mathrm{~g} \rightarrow{ }^{4} \mathrm{~A}_{2} \mathrm{~g} \\
{ }^{4} \mathrm{~T}_{1} \mathrm{~g} \rightarrow{ }^{4} \mathrm{~T}_{2} \mathrm{~g}(\mathrm{P})\end{array}$ \\
\hline$\left[\mathrm{Ni}(\mathrm{PCA})_{2}(\mathrm{Cl})_{2}\right]$ & $\begin{array}{l}296 \\
450 \\
583 \\
962 \\
\end{array}$ & $\begin{array}{l}33783 \\
22222 \\
17152 \\
10395 \\
\end{array}$ & $\begin{array}{l}2.250 \\
0.260 \\
0.109 \\
0.020\end{array}$ & $\begin{array}{c}2250 \\
260 \\
109 \\
20\end{array}$ & $\begin{array}{c}\text { L.F. } \\
{ }^{3} \mathrm{~A}_{1} \mathrm{~g} \rightarrow{ }^{3} \mathrm{~T}_{1} \mathrm{~g}(\mathrm{P}) \\
{ }^{3} \mathrm{~A}_{1} \mathrm{~g} \rightarrow{ }^{3} \mathrm{~T}_{1} \mathrm{~g}(\mathrm{~F}) \\
{ }^{3} \mathrm{~A}_{2} \mathrm{~g} \rightarrow{ }^{3} \mathrm{~T}_{2} \mathrm{~g}(\mathrm{P})\end{array}$ \\
\hline$\left[\mathrm{Cu}(\mathrm{PCA})_{2}(\mathrm{Cl})_{2}\right]$ & $\begin{array}{l}312 \\
595\end{array}$ & $\begin{array}{l}32051 \\
16806\end{array}$ & $\begin{array}{l}1.966 \\
0.190\end{array}$ & $\begin{array}{c}1966 \\
190\end{array}$ & $\begin{array}{c}\text { L.F. } \\
{ }^{2} \mathrm{Eg} \rightarrow{ }^{2} \mathrm{~T}_{2} \mathrm{~g}\end{array}$ \\
\hline$\left[\mathrm{Zn}(\mathrm{PCA})_{2}(\mathrm{Cl})_{2}\right]$ & $\begin{array}{l}311 \\
589\end{array}$ & $\begin{array}{l}32154 \\
16277\end{array}$ & $\begin{array}{l}1.843 \\
0.100\end{array}$ & $\begin{array}{c}1843 \\
100\end{array}$ & $\begin{array}{c}\text { L.F } \\
\text { C.T }(\mathrm{M} \rightarrow \mathrm{L})\end{array}$ \\
\hline$\left[\mathrm{Cd}(\mathrm{PCA})_{2}(\mathrm{Cl})_{2}\right]$ & $\begin{array}{l}297 \\
584\end{array}$ & $\begin{array}{l}33670 \\
17123\end{array}$ & $\begin{array}{l}2.210 \\
0.105\end{array}$ & $\begin{array}{c}2210 \\
105\end{array}$ & $\begin{array}{c}\text { L.F } \\
\text { C.T }(\mathrm{M} \rightarrow \mathrm{L})\end{array}$ \\
\hline$\left[\mathrm{Hg}(\mathrm{PCA})_{2}(\mathrm{Cl})_{2}\right]$ & $\begin{array}{l}296 \\
586\end{array}$ & $\begin{array}{l}33783 \\
17064\end{array}$ & $\begin{array}{l}2.387 \\
0.138\end{array}$ & $\begin{array}{c}2383 \\
138\end{array}$ & $\begin{array}{c}\text { L.F } \\
\text { C.T }(\mathrm{M} \rightarrow \mathrm{L})\end{array}$ \\
\hline
\end{tabular}




\section{FT-IR Spectra}

These spectra exhibited marked difference between bands Fig.(4) belonging to the stretching vibration at(1248) $\mathrm{cm}^{-1}$ in the spectrum of the ligand assigned to $v(\mathrm{C}=\mathrm{S})$ in the range between (1157-1174) $\mathrm{cm}^{-1}$ shifted lower frequency by (74-91) $\mathrm{cm}^{-1}$ in the spectra to the complexes, indicating involvement of thione groups sulfur in the coordination[14], while the band caused by $\mathrm{v}(\mathrm{C}=\mathrm{O}$ amido $)$ in the range between (1593-1596) $\mathrm{cm}^{-1}$ shifted to lower frequencies by $(85-82) \mathrm{cm}^{-1}$ suggesting of the possibility of the coordination of ligand(PCA) through the $(\mathrm{O}$ atom) of the $(\mathrm{C}=\mathrm{O})$ group. The stretching vibration band of $v(\mathrm{NH})$ either show no change or very little in their frequency(3348-3357) $\mathrm{cm}^{-1}$ therefor indicating do not coordinate too the metal ion[15].(M-O)\&(M-S) were confirmed by the presence of the stretching tremor of $v(\mathrm{M}-\mathrm{O})$, $\mathrm{v}(\mathrm{M}-\mathrm{S}), \mathrm{v}(\mathrm{M}-\mathrm{Cl})$ around (374-472) $\mathrm{cm}^{-1}$, (322$378) \mathrm{cm}^{-1}$ and $(251-283) \mathrm{cm}^{-1}$ respectively [16],Table(2) describes the important bands and assignment for all complexes and Fig.(4): Infrared spectrum of one from prepared complexes $\left[\mathbf{H g}(\mathbf{P C A})_{2} \mathbf{C l}_{2}\right]$.

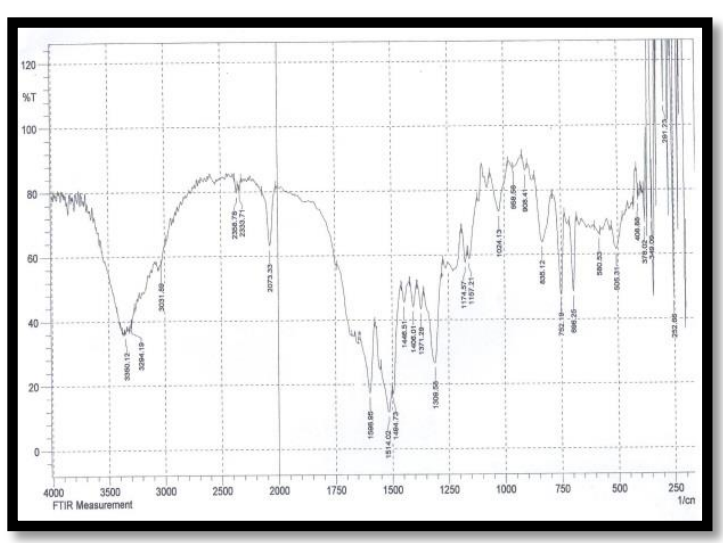

Fig.(4): Infrared spectrum of complex $\left[\mathrm{Hg}(\mathrm{PCA})_{2} \mathrm{Cl}_{2}\right]$.

\section{Magnetic moment}

The values of measured magnetic susceptibility \& effective magnetic moment $\left(\mu_{\text {eff }}\right)$ for the $\mathrm{Mn}(\mathrm{II}), \mathrm{Co}(\mathrm{II}), \mathrm{Ni}(\mathrm{II}), \mathrm{Cu}(\mathrm{II})$ complexes are shown in Table(1). Mn(II), $\mathrm{Co}(\mathrm{II}), \mathrm{Ni}(\mathrm{II})$ and $\mathrm{Cu}(\mathrm{II})$ complexes exhibit $\mu_{\text {eff }}$ (5.94, $4.49,2.95,1.76)$ B.M respectively, which impute to a normal values for octahedral complexes.[17]

\section{Electronic spectra for complexes \\ $-\left[\mathrm{Mn}(\mathbf{P C A})_{2} \mathbf{C l}_{2}\right] \mathbf{d}^{5}$}

The green complex of $\mathrm{Mn}$ (II) shows band at $(33670) \mathrm{cm}^{-1}$ due to ligand field and other bands at(23809) $\mathrm{cm}^{-1} \&$ (17123) $\mathrm{cm}^{-1}$ which are caused by the electronic transfer (L.F), ${ }^{6} \mathrm{~A}_{1} \mathrm{~g}$ $\rightarrow{ }^{4} \mathrm{~T}_{2 \mathrm{~g}(\mathrm{G})} \&{ }^{6} \mathrm{~A}_{1} \mathrm{~g} \longrightarrow{ }^{4} \mathrm{~T}_{1} \mathrm{~g}$ (G) respectively, suggesting octahedral geometry around $\mathrm{Mn}$ (II) ion [18 ].

\section{$-\left[\mathrm{Co}(\mathrm{PCA})_{2} \mathrm{Cl}_{2}\right] \mathrm{d}^{7}$}

The spectrum of the green complex gave four band at (32362) $\mathrm{cm}^{-1}$, (22988) $\mathrm{cm}^{-1}$, (17152) $\mathrm{cm}^{-1} \&(10718) \mathrm{cm}^{-1}$ attributed to (L.F)with ${ }^{4} \mathrm{~T}_{1} \mathrm{~g} \longrightarrow{ }^{4} \mathrm{~T}_{1} \mathrm{~g}_{(\mathrm{p})},{ }^{4} \mathrm{~T}_{1} \mathrm{~g} \longrightarrow{ }^{4} \mathrm{~A}_{2} \mathrm{~g} \quad$ \& ${ }^{4} \mathrm{~T}_{1} \mathrm{~g} \rightarrow{ }^{4} \mathrm{~T}_{2} \mathrm{~g}_{(\mathrm{F})}$ respectively,"Racah inter electronic repulsion parameter" $\left(\mathrm{B}^{-}\right)$was found to be (532.4) $\mathrm{cm}^{-1}$, from the relation $\beta=\mathrm{B}^{-} / \mathrm{B}^{0}$, was found to equal (0.548), these parameter are accepted to $\mathrm{Co}$ (II) octahedral complex[19].

\section{$-\left[\mathrm{Ni}(\mathrm{PCA})_{2} \mathrm{Cl}_{2}\right] \mathrm{d}^{8}$}

The spectrum of green complex of $\mathrm{Ni}(\mathrm{II})$ has indicated the following electronic transfer (L.F) with ${ }^{3} \mathrm{~A}_{2} \mathrm{~g} \longrightarrow{ }^{3} \mathrm{~T}_{1} \mathrm{~g}_{(\mathrm{P})}$, ${ }^{3} \mathrm{~A}_{1} \mathrm{~g} \longrightarrow{ }^{3} \mathrm{~T}_{1} \mathrm{~g}_{(\mathrm{F})} \&{ }^{3} \mathrm{~A}_{2} \mathrm{~g} \longrightarrow{ }^{3} \mathrm{~T}_{2} \mathrm{~g}_{(\mathrm{F})}$, transition at $(33783) \mathrm{cm}^{-1},(22222) \mathrm{cm}^{-1},(17152) \mathrm{cm}^{-1} \&$ $(10395) \mathrm{cm}^{-1}$ respectively, the $\left(B^{-}\right)$value is found to be $(545.9) \mathrm{cm}^{-1}$, while $\beta$ was equal to $(0.524)$ these are the characteristics for octahedral complexes of $\mathrm{Ni}(\mathrm{II})[20] . \mathrm{Fig}(6)$ show that.

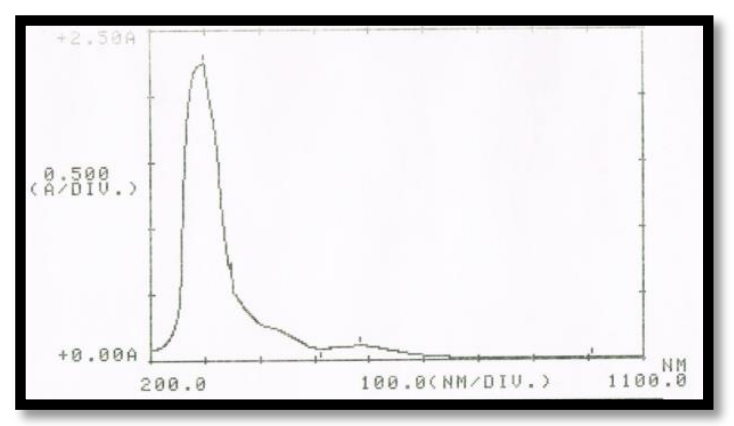

Fig(6):U.V spectrum of complex $\left[\mathrm{Ni}(\mathrm{PCA})_{2}(\mathrm{Cl})_{2}\right]$

\section{- $\left[\mathrm{Cu}(\mathrm{PCA})_{2} \mathrm{Cl}_{2}\right] \mathrm{d}^{9}$}

The spectrum of green complex of $\mathrm{Cu}$ (II)Fig. (6) shows two bands at $(32051) \mathrm{cm}^{-1}$ and (16806) $\mathrm{cm}^{-1}$ caused to (L.F.) ${ }^{2} \mathrm{Eg} \longrightarrow$ ${ }^{2} \mathrm{~T}_{2} \mathrm{~g}$ transition respectively, which was a good agreement for distorted octahedral complex for $\mathrm{Cu}(\mathrm{II})$ ion[21,22]. 
-The complexes of $\left[\mathrm{Zn}(\mathrm{PCA})_{2} \mathrm{Cl}_{2}\right]$ $\left[\mathbf{C d}(\mathbf{P C A})_{2} \mathbf{C l}_{2}\right]$ and $\left[\mathbf{H g}(\mathbf{P C A})_{2} \mathbf{C l}_{2}\right.$ ]show only( C.T) and (L.F)of $(\mathrm{M} \rightarrow \mathrm{L})$ in range (33783-116977) $\mathrm{cm}^{-1}$ [23-24]. All transition with their assignments are summarized in Table (3).

\section{Conclusions}

As demonstrated by looking at the research and, the ligand (PCA) behaves as bidentate on coordination with $\mathrm{Mn}$ (II), $\mathrm{Co}$ (II), $\mathrm{Ni}(\mathrm{II}), \mathrm{Cu}(\mathrm{II}), \mathrm{Zn}(\mathrm{II}), \mathrm{Cd}(\mathrm{II})$ and $\mathrm{Hg}$ (II) ions via oxygen atom of carbonyl group and sulfer atom of $(\mathrm{C}=\mathrm{S})$ group, also coordination with $(\mathrm{M}-\mathrm{Cl})$ so suggesting octahedral geometry around metal ions for all prepared complexes that depending on the basis of molar conductivity, magnetic moment, spectroscopic studies(FTIR,UV-Vis \& atomic absorption)for all prepared complexes and" ${ }^{1} \mathrm{H}-{ }^{13} \mathrm{C}$ NMR"only for the ligand(PCA) .Fig(7):The proposed chemical structure formula of the complexes

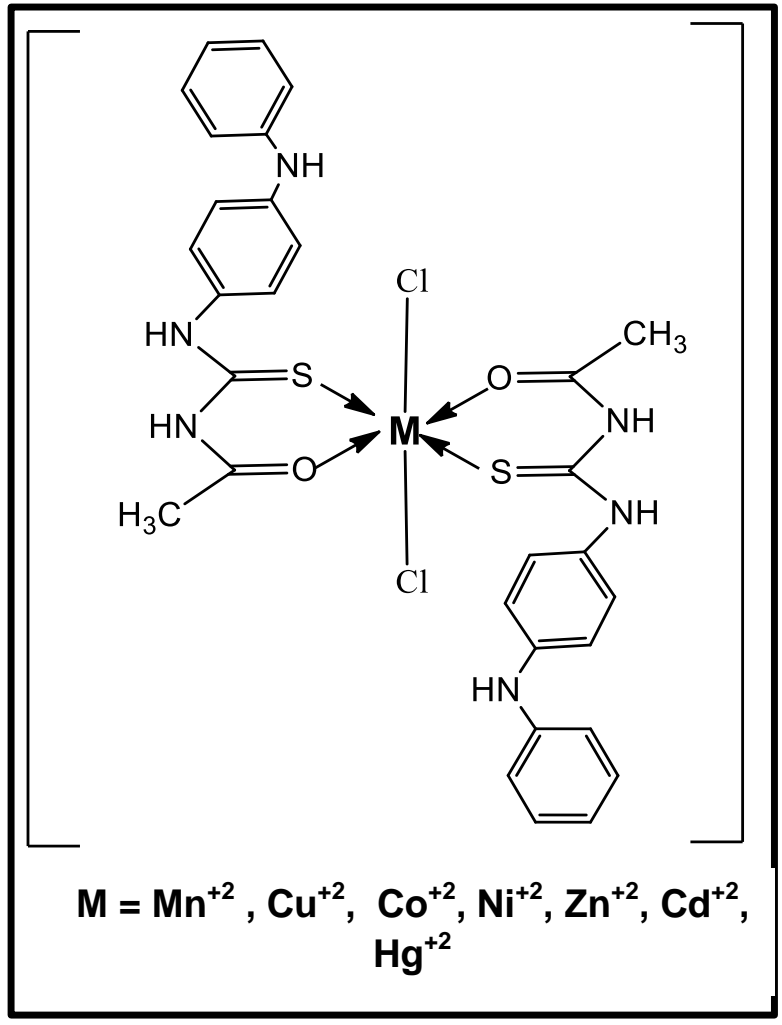

Fig(7):The proposed chemical structure formula of the complexes

\section{References}

1- DeBruin, L., \& Josephy, P. (2002). Perspives on the chemical etiology of breast cancer. Environ Health Persp, 110, 119-128.

2- DeBruin, L., Pawliszyn, J., \& Josephy, P. (1999). Detection of monocyclic aromatic amines, possible mammary carcinogens, in human milk. Chem Res Toxciol, 12, 78-82.

3- Robert J. Turesky and Loic Le Marchand (2011). Metabolism and Biomarkers of Heterocyclic Aromatic Amines in Molecular Epidemiology Studies: Lessons Learned from Aromatic Amines. Chem Res Toxciol. 1214-1169:(8)24.

4- Md. Serajul H. Faizi, Ashraf Mashrai,b M. Shahid,b, and Musheer Ahmada(2014). N 1-[(1H-Imidazol-2yl)methylᄀidene]-N 4-phenyl-benzene1,4-di-amine. Acta Crystallographica Section E.70(Pt 7).

5- Eslam Salahifara and Davood Nematollahi .(2015).Electrochemical generation of a Michael acceptor: a green method for the synthesis of 4amino-3-

(phenylsulfonyl)diphenylamine derivatives. New J. Chem., 2015,39, 3852-3858.

6- Ammar Jihad Alabdali.(2012) Synthesis and Characterization of New Complexes of (N-P-Amino Diphenyl Amine) Amino (2-Hydroxy Phenyl) Acetonitrile Ligand with Some Transition Metal Ions Journal of Applied Chemistry (IOSR-JAC). 22785736. Volume 3, Issue 2 .PP 05-10

7- L.F. Fieser and M. Fieser.(1961)" Advanced Organic Chemistry " Reinhold PuplishingCorporation,New York;p.14.

8- G.S. Singh and T. Pheko,(2008),"Spectroscopic

Charaterization of the 1- Substituted 3,3'-Diphenyl-4-(2'-

hydroxyphenyl)azetidine-2ones:Applic-ation of ${ }^{13} \mathrm{C}$ NMR, ${ }^{1} \mathrm{H}$ NMR and Mass Spectroscopy", spectrochim.Acta, Part A. ,70,595-600. 
9- Cary, F.A.(2005) Organic Chemistry, 6th Ed. the M.C Graw-Hill companies, Inc.,New York.

10- .Silverstein, R.M. ; Bassler, G.C. and Morrill, T.C;(1981) Spectroscopicidentification of organic compounds, 4th Ed., John Wiley and Sons, New York.

11- Marah,J.;(1991).AdvancedOrganic Chemistry, 4th Ed., J. Wiley and Sons, New York .

12- .Dyes, .R.J; (1996).Application of absorption spectroscopy of organic compounds, Prentice -Hall,Inc., Englewood cliffs,N,J.London.

13- Diebbar-Sid, S., Benali-Baitich, O. and Deloume, J.P.; (2001), Synthetic and Structural Studies of Some Bivalent Transition Metal Complexes with Oxygen and Nitrogen Containing Schiff Base ;J. mol. Struct., 569: 121.

14- Nawar, N.; El-swwah, I.I., Hosny, N.M. and Mostafa, M.M., (2011) "Novel mono-and binuclear complexes derived from N-benzoyl-Nglycylthiourea(BGH)with some transition metal ions", Arabian Journal of chemistry, 17(1):434-438

15- Nakamoto, K., (1996), "'Infrared spectra of inorganic and coordination compounds", 4th Ed. , John wily and Sons , New York .

16- Al- Hashimi, S. M.; Sarhan, B.M. and Salman, A.W., (2002), "Synthesis and characterization of $\mathrm{N}$-acetyl -Dl tryptophan with some metal ions", Iraq J. Chem., 28: 1-11.
17- Mulay,L., (1977)Magnetic Susceptibility.John wiley and sons;New York;part1,vol(4).

18- Sarhan, B .M.; Abed, A.H. and Rumez, R.M. (2013) "Synthesis and characterization of some mixed ligand complexes of quinaldic acid and $\alpha$ picoline with some metal salts";ALMustansiriyah Journal of science,24(4): 65-74.

19- .18Lever, A.B.P.; (1968) "Inorganic electronic spectroscopy", Elsevier publishing company Amsterdam, London, New York.

20- .19Drugo,R.S.; (1965) "Physical methods in inorganic chemistry", Vann strand-Reinhold, NewYork.

21- .20Dichakjian,S. andFarrago,M.E. (1985) "Metal complexes of 2-amino-5nitrothiazole"; Inorg.Chem.Acta,108: 247-259.

22- .21Walton,R.A.; (1966) "Some donor properties of 1,4-thioxane:complexes with transition metal halides";Inorg.Chem.,5(4): 643-649.

23- .22Arjmamd,F.; Parveen, S. and Mohapatra, D.K. (2012) "Synthesis, characterization of $\mathrm{Cu}(\mathrm{II})$ and $\mathrm{Zn}$ (II) complexes of proline-glycine and proline-leucinetetrapeptides:in vitro DNA binding and cleavage studies", Inorg.Chem.Acta,388(15): 1-10.

24- .Naik,A.D.; Beck, J.; Dirtu, M.N. and Bebrone, C. (2011) "Zinc complexes with 1,2,4-triazole functionalized amino acid derivatives, synthesis, structure and $\beta$-lactamasessay", Inorg.Chem.Acta,368: 21-28. 
تحضير ودراسة طيفية لليكاند الجديا

N-((4-(phenylamino)phenyl)carbamothioyl)acetamide

مع معقداته لبعض القلزات ثنائية التكاقؤ

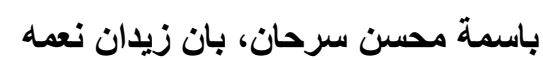
قالخم الكيمياء/ كلية التربية للعلوم الصرفة فئة (ابن الهيثم ) / جامعة بغداد

(4-فنل امين)فنل (كارباموثايول) استامايد (PCA)هو ليكاند جديد تم تحضيره من تفاعل (4- امينو ثنائي فنل امين) مـع (بـار ا استايل

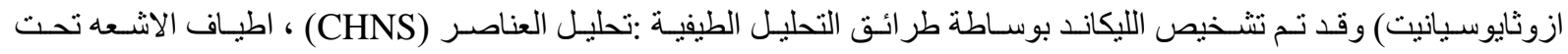

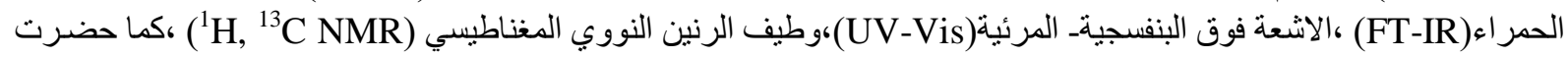

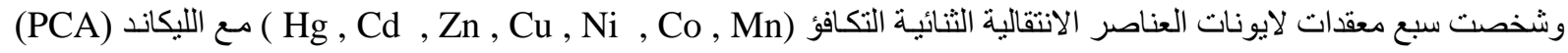

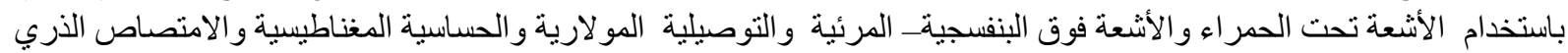
و استتنج من الدر اسات و التشخيصات أن المعقدات ذات شكل ثماني السطوح.

الكلمات المفتاحية : 4- امينو ثنائي فنل امين، ايونات فلزية ثنائية التكافؤ، معقدات 